\title{
Wanneer bevordert en wanneer hindert werkdruk het werkplekleren?*
}

\author{
Joris Van Ruysseveldt \& Marius van Dijke*
}

\section{Inleiding}

Onze steeds complexere kenniseconomie vereist dat werknemers continu leren om hun competenties in het werk op peil te houden (Coetzer, 2007; Mayer \& Solga, 2008). Onderzoek laat zien dat mogelijkheden tot leren terwijl men werkt (d.w.z. informele leermogelijkheden, Rau, 2006) een effectieve manier bieden om de vereiste kennis en vaardigheden te ontwikkelen (Rau, 2006; Van Ruysseveldt \& Taverniers, 2010). Informeel leren is zelfs effectiever en leidt tot betere leeruitkomsten dan formeel leren (Desjardins \& Tuijnman, 2005; Skule, 2004). Mogelijkheden voor informeel werkplekleren bevorderen de productiviteit, de economische groei en de competitiviteit van organisaties op de langere termijn (Desjardins \& Tuijnman, 2005) en zijn gunstig voor de werkgelegenheid en inzetbaarheid van arbeidskracht (Coetzer, 2007; Mayer \& Solga, 2008). Informeel werkplekleren heeft ook positieve gevolgen voor werknemers: het zorgt voor een beter aanpassingsvermogen aan organisatieveranderingen (Skule, 2004), het bevordert hun welzijn en de gezondheid middels het reduceren van stress (Holman \& Wall, 2002; Paulsson, Ivergård \& Hunt, 2005; Rau, 2006; Van Ruysseveldt, Verboon \& Smulders, 2011; Van Ruysseveldt, Proost \& Verboon, 2011) en het bevordert de werkmotivatie (Parker, Chmiel \& Wall, 1997; Morrison, Cordery, Girardi \& Payne, 2005; Schaufeli, Bakker \& Van Rhenen, 2009).

Deze talrijke gunstige effecten van informeel werkplekleren maken dat een belangrijke taak voor onderzoekers is om meer inzicht te verwerven in werkgerelateerde factoren en mechanismen die dat leren bevorderen dan wel belemmeren (vgl. Frese \& Zapf, 1994; Karasek \& Theorell, 1990; Morrison et al., 2005; Rau, 2006; Wielenga-Meijer, Taris, Kompier \& Wigboldus, 2006). Dergelijke inzichten moeten ertoe bijdragen dat job (re)design interventies gericht op het ontwikkelen van informele leermogelijkheden, trefzekerder kunnen worden opgezet en uitgevoerd. Echter, onze kennis over de invloed van specifieke werkkenmerken op de beschikbaarheid van informele leermogelijkheden is tot op zekere hoogte ambigu en bepaalde punten blijven nog onopgelost (Desjardin \& Tuijnman, 2005; Marsick \& Volpe, 1999). Dit geldt in het bijzonder voor de samenhang tussen werkeisen en werkplekleren.

* Voor dit onderzoek is gebruik gemaakt van de SERV-databank 'Vlaamse Werkbaarheidsmonitor', de inhoud van de tekst bindt alleen de auteurs.

** J. Van Ruysseveldt is verbonden aan de Open Universiteit Nederland, Faculteit Psychologie, Heerlen. Correspondentieadres: J. Van Ruysseveldt, Open Universiteit Nederland, Postbus 2960, 6401 DL Heerlen, tel. 045-5762839, e-mail: joris.vanruysseveldt@ou.nl. M. van Dijke is verbonden aan de Rotterdam School of Management van de Erasmus Universiteit Rotterdam. 
Meermaals is betoogd dat de werkeisen in een bepaalde job mogelijkheden tot informeel werkplekleren bevorderen (bijv. Frese \& Zapf, 1994; Karasek, 1979). Het empirische bewijs voor deze positieve samenhang tussen werkeisen en informeel werkplekleren is echter erg gemengd (voor een overzicht, zie: Taris \& Kompier, 2005). Dit bracht sommige onderzoekers (bijv. De Jonge \& Kompier, 1997; Wielenga-Meijer et al., 2010) tot de suggestie dat de relatie tussen werkeisen, zoals de werkdruk, en werkplekleren mogelijk niet-lineair is. Daarmee brachten ze een idee tot leven dat al eerder was geformuleerd door Karasek, die benadrukte dat werkplekleren wel gestimuleerd wordt door hoge, maar niet door overweldigend hoge werkdruk $(1979,1998)$.

In deze studie richten we ons op de relatie tussen een specifieke en belangrijke werkeis, namelijk werkdruk, en informeel werkplekleren. We willen twee condities identificeren die samen bepalen wanneer werkdruk mogelijkheden tot informeel werkplekleren bevordert dan wel belemmert (zie voor een vergelijkbare studie op oudere data van de Vlaamse werkbaarheidsmonitor: Van Ruysseveldt \& Van Dijke, 2011). Ten eerste argumenteren we dat op relatief lage niveaus van werkdruk, werkdruk positief samenhangt met informele leermogelijkheden, terwijl op relatief hoge niveaus van werkdruk, werkdruk daar negatief mee samenhangt. We veronderstellen met andere woorden dat werkdruk en werkplekleren curvilineair met elkaar verbonden zijn en dat de bijhorende curve de vorm aanneemt van een omgekeerde $U$.

Ten tweede identificeren we taakautonomie als een moderator in de relatie tussen werkdruk en werkplekleren. We beargumenteren dat lage niveaus van autonomie verhinderen dat de potentiële positieve gevolgen van werkdruk voor werkplekleren (d.w.z. op relatief lage niveaus van werkdruk) materialiseren. Aan de andere kant zullen hoge niveaus van autonomie de potentieel negatieve gevolgen van werkdruk (d.w.z. op hoge niveaus van werkdruk) minder destructief laten zijn voor het leerproces. Figuur 1 beeldt grafisch uit hoe we de relatie tussen werkdruk en werkplekleren veronderstellen als functie van autonomie.

\section{Werkdruk en informeel werkplekleren}

Marsick en Volpe (1999) beschrijven informeel leren als overwegend ongestructureerd, experimenteel en non-institutioneel. Het betreft, zoals Rau (2006) stelt, leren tijdens de uitvoering van het werk, en niet middels formele opleidingen of trainingen. Een kernvraag met betrekking tot informeel werkplekleren betreft de mate waarin werkkenmerken, zoals werkdruk en autonomie, de ontwikkeling van nieuwe competenties bevorderen of belemmeren. Taris en Kompier (2005) stellen vast dat arbeids- en organisatiepsychologen dit vraagstuk hoofdzakelijk behandeld hebben in het kader van het bekende Job Demands Control (JDC) model van Karasek (1979; Karasek \& Theorell, 1990). Dit model stelt dat hoge werkeisen, zoals werkdruk, werknemers aanzetten tot actief leren, dat wil zeggen: tot het initiëren van activiteiten gericht op het aanscherpen van bestaande en het verwerven van nieuwe competenties. Een hoge werkdruk spoort werknemers namelijk aan om meer effectieve werkstrategieën en -gedragingen te zoeken waarmee ze 
Figuur 1 De samenhang tussen werkdruk en leermogelijkheden als functie van autonomie

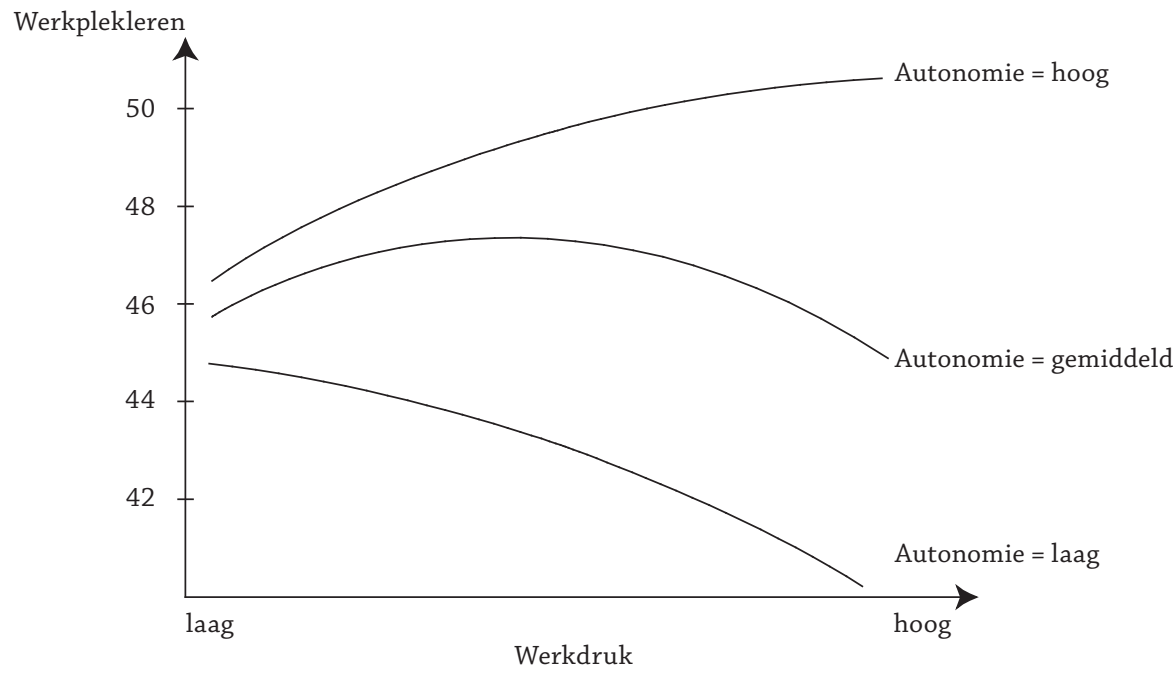

hun werkdoelen beter kunnen bereiken. Dit streven naar effectiever werken onder hoge druk lokt reflectie over alternatieve oplossingen voor werkgerelateerde problemen uit, net als exploratie van alternatieve werkstrategieën en -gedragingen. Als de nieuwe gedragspatronen effectief blijken te zijn, dan worden ze volgens Karasek (1998) geïncorporeerd in het repertoire van gedragsstrategieën die de werknemer inzet om met de eisen van de job om te gaan, dat wil zeggen: ze worden 'geleerd' (Karasek, 1998; zie ook Taris \& Kompier, 2005).

In 2005 publiceerden Taris en Kompier (2005) een overzicht van 18 studies over werkplekleren in de context van het JDC-model. Zij vonden geen overtuigend empirisch bewijs voor de veronderstelde positieve samenhang tussen werkdruk en werkplekleren. Sommige studies rapporteerden inderdaad positieve relaties tussen werkdruk en indicatoren voor werkgerelateerd leren (bijv. Skule, 2004; zie ook De Witte et al., 2007; Rau, 2006). Daartegenover vonden andere studies een niet-significante samenhang tussen werkdruk en werkplekleren (bijv. De Jonge, Janssen \& Van Breukelen, 1996; Houkes, Janssen, De Jonge \& Nijhuis, 2001; Morrison et al., 2005; zie ook Van Ruysseveldt \& Taverniers, 2010; Van Ruysseveldt, Proost \& Verboon, 2011), en nog andere zelfs een negatieve relatie (bijv. Parker \& Sprigg, 1999; Taris, Kompier, De Lange, Schaufeli \& Schreurs, 2003; zie ook Van Ruysseveldt, Verboon \& Smulders, 2011). Zoals gesteld is een mogelijke verklaring voor deze inconsistente resultaten dat de relatie tussen werkdruk en werkplekleren niet rechtlijnig, maar kromlijnig van aard is (Karasek, 1998; Wielenga-Meijer et al., 2010). Vertrekkend van deze erg uiteenlopende onderzoeksbevindingen poneren wij dat op lagere niveaus van werkdruk, een toename in de werkdruk het werkplekleren bevordert, maar op hogere niveaus van werkdruk buigt deze toename in werkplekleren af om uiteindelijk te resulteren in een dalende curve bij de hoogste niveaus van werkdruk (zie figuur 1; middelste curve). 
Op theoretische gronden is aannemelijk dat hoge niveaus van werkdruk het werkplekleren ongunstig beïnvloeden. Theoretische stressmodellen zoals het JDCmodel (Karasek, 1979), de Conservation of Resources (COR) theorie (Hobfoll, 2002; zie ook: Lee \& Ashforth, 1996) en het Job Demands-Resources (JDR) model (Bakker \& Demerouti, 2007) beklemtonen dat werkeisen, zoals een hoge werkdruk, een proces van energie-uitputting in gang zetten dat kan resulteren in burn-out en gezondheidsklachten (zie ook: LePine, LePine \& Jackson, 2004). Het JDRmodel bijvoorbeeld stelt dat hoge werkeisen fysieke en mentale inspanning vereisen die aanleiding geven tot een voortdurende uitputting van de energiereserves van de werknemers en daarom samenhangen met psychologische kosten zoals toegenomen emotionele uitputting (Bakker \& Demerouti, 2007; Schaufeli et al., 2009). In het verlengde hiervan tonen experimentele studies (bijv. Eysinck \& Calvo, 1992; Warr \& Downing, 2000) aan dat indicatoren van energie-uitputting, zoals depressie, geassocieerd zijn met een vermindering van de energie die noodzakelijk is voor het presteren op cognitieve taken die aanzetten tot leren (vgl. Holman \& Wall, 2002). Concluderend, de energie-uitputtende eigenschappen van werkdruk zorgen ervoor dat op hogere niveaus van werkdruk processen van werkplekleren verstoord worden en de effectiviteit ervan gedwarsboomd wordt.

Een ander mechanisme ter onderbouwing van de negatieve relatie tussen werkdruk en werkplekleren op hoge niveaus van werkdruk wordt aangereikt vanuit de actietheorie (Frese \& Zapf, 1994). Uitgaande van deze theorie stellen Taris, Kompier en Wielenga-Meijer (2006) dat hoge werkdruk de taakregulatie verstoort, wat leidt tot de obstructie van voorgenomen leergedrag, met als gevolg dat werknemers hun toevlucht zoeken in geautomatiseerd werkgedrag (zie ook: LePine et al., 2004; Taris \& Kompier, 2005; Wielenga-Meijer et al., 2006). Op hoge niveaus van werkdruk raken werknemers vastgepind op onmiddellijke doelrealisatie. Omdat ze zich strak richten op direct productief gedrag verdampt de tijd nodig voor activiteiten zoals reflectie, exploratie en experimentatie, acties die noodzakelijk zijn voor het in gang zetten en houden van het leerproces (Ellström, 2001).

Bovenstaande analyse brengt ons bij onze eerste hypothese.

Hypothese 1: Bij lage werkdruk hangt een toename in de werkdruk samen met een toename in werkplekleren. Bij hoge werkdruk daarentegen hangt een toename in de werkdruk samen met een afname in werkplekleren.

\section{Werkdruk, werkplekleren en autonomie}

Een belangrijke veronderstelling in het JDC-model (Karasek, 1979) is dat de effectiviteit van werkdruk in het stimuleren van werkplekleren afhankelijk is van andere werkkenmerken, in het bijzonder de mate van autonomie in de taakuitvoering. Meer specifiek poneert de 'actief leren'-hypothese uit het JDC-model dat de combinatie van hoge werkdruk en hoge taakautonomie (d.w.z. actieve jobs) het meest bevorderlijk is voor werkplekleren (Karasek, 1979; Karasek \& Theorell, 1990). In het huidige onderzoek beschouwen we autonomie daarom als een noodzakelijke voorwaarde waaronder werkdruk het werkplekleren bevordert. Werk- 
druk spoort weliswaar aan tot een zoektocht naar meer effectieve werkstrategieën en -gedragingen (Taris et al., 2006), maar de succesvolle implementatie van die nieuwe werkstrategieën is afhankelijk van mogelijkheden voor flexibele aanpassing aan onvoorspelbare en onvoorzienbare omstandigheden (Frese \& Zapf, 1994). Anders gezegd, wil werkdruk meer werkplekleren stimuleren, dan moeten werknemers autonome beslissingen kunnen nemen, bijvoorbeeld met betrekking tot hun werkmethoden en de taakvolgorde (Holman \& Wall, 2002; WielengaMeijer et al., 2010).

Meer specifiek beargumenteren wij dat op lage niveaus van autonomie de potentieel positieve (d.w.z. leren bevorderende) gevolgen van werkdruk die we verwachten (op relatief lage niveaus van werkdruk; zie hypothese 1) zullen uitblijven. Hoewel de werkdruk de werknemer voor voldoende uitdagende werkdoelen stelt, ontneemt lage autonomie die werknemer de noodzakelijke bronnen en instrumenten om de relevante aspecten van het werk aan te passen aan de voorgenomen veranderingen in de werkpraktijk. Daarmee verdampt het prikkelende potentieel van een uitdagende werkdruk en rest de werknemer weinig anders dan terug te vallen op geautomatiseerd gedrag (Frese \& Zapf, 1994; Taris et al., 2006). Op lage niveaus van autonomie verwachten we daarom dat een toename van werkdruk steeds zal samenhangen met verminderde mogelijkheden tot werkplekleren, zelfs op lage niveaus van werkdruk (zie onderste curve in figuur 1).

Bovendien veronderstellen we dat de negatieve relatie tussen werkdruk en werkplekleren bij een lage mate van autonomie progressief sterker wordt naarmate hogere niveaus van werkdruk bereikt worden (zie het rechtergedeelte van de onderste curve in figuur 1). Zoals eerder beargumenteerd worden de energie-uitputtende eigenschappen van werkdruk manifester op hogere niveaus van werkdruk. Bij een steeds toenemende werkdruk vloeit de energie noodzakelijk voor cognitieve prestaties, zoals leren, weg (Karasek \& Theorell, 1990; Eysinck \& Calvo, 1992; Warr \& Downing, 2000; Holman \& Wall, 2002). Bovendien wordt de werknemer, door de graduele inkrimping van de tijd noodzakelijk voor niet-productieve maar kritische leergedragingen, zoals reflectie, exploratie en experimentatie, gedwongen terug te vallen op geautomatiseerde gedragingen (Frese \& Zapf, 1994; Ellström, 2001; Taris et al., 2006). Deze redeneerlijn brengt ons bij de tweede hypothese.

Hypothese 2: Bij lage autonomie gaat een toename in werkdruk samen met een afname in werkplekleren, en deze negatieve relatie wordt sterker naarmate de werkdruk stijgt.

Omgekeerd, en opnieuw in het verlengde van Karasek's (1979; 1998) 'actief leren'-hypothese, verwachten wij dat werkdruk bevorderlijk is voor werkplekleren op voorwaarde dat de autonomie hoog is (Karasek \& Theorell, 1990; Taris \& Kompier, 2005; De Witte et al., 2007). Hoge taakeisen bevorderen het werkplekleren omdat ze werknemers uitdagen om nieuwe en meer doeltreffende werkstrategieën te ontwikkelen. Hoge taakautonomie faciliteert werkplekleren omdat werknemers daardoor over de noodzakelijke mogelijkheden beschikken om te exploreren en te experimenteren met die nieuwe werkstrategieën. Door autonomie kan 
de prikkelende uitdaging van stijgende werkdruk dus effectief omgezet worden in actief ingrijpen in de wijze waarop het werk wordt aangepakt.

We verwachten echter dat deze bevorderlijke invloed van een stijgende werkdruk gradueel vermindert op hogere niveaus van werkdruk. Bij een (te) hoge werkdruk treden namelijk de energie-uitputtende eigenschappen op de voorgrond (Eysinck \& Calvo, 1992; Warr \& Downing, 2000), terwijl ook de tijd nodig voor niet-productieve, maar kritische leergedragingen niet meer beschikbaar is en daarom teruggevallen moet worden op geautomatiseerd werkgedrag (Frese \& Zapf, 1994; Ellström, 2001; Taris et al., 2006). Onze derde hypothese luidt daarom als volgt.

Hypothese 3: Bij hoge autonomie gaat een toename in werkdruk samen met een toename in werkplekleren, maar deze positieve relatie wordt zwakker naarmate de werkdruk stijgt.

\section{Methode}

\subsection{Steekproef en procedure}

Het onderzoek maakt gebruik van de data verzameld door de Stichting Technologie Vlaanderen (STV) van de Sociaaleconomische Raad voor Vlaanderen (SERV) in het kader van de Vlaamse Werkbaarheidsmonitor (WBM). De WBM is een schriftelijke cross-sectionele survey die driejaarlijks de werkomstandigheden van een representatieve steekproef uit de Vlaamse beroepsbevolking in kaart brengt (Bourdeaud'hui \& Vanderhaeghe, 2007). Voor het huidige onderzoek zijn de meest recente data, die uit 2010, gebruikt (voor analyses op oudere data, zie: Van Ruysseveldt \& Van Dijke, 2011). De WBM-data worden verzameld bij een random steekproef van 20.000 Vlaamse werknemers uit het DIMONA-personeelsregister. Doordat sinds 1 januari 2003 alle werkgevers in België verplicht zijn tot onmiddellijke elektronische aangifte van tewerkstelling via de DIMONA-registratie, geeft het DIMONA-personeelsregister gekoppeld aan de woonplaats steeds een accuraat en up-to-date beeld van alle loontrekkenden in het Vlaamse gewest op een gegeven tijdstip. Zoals in de voorafgaande jaren van dataverzameling (2004 en 2007) was de gerealiseerde WBM-steekproef representatief voor de Vlaamse beroepsbevolking met betrekking tot geslacht, leeftijd en sector van tewerkstelling (Bourdeaud'hui \& Vanderhaeghe, 2007; Vanroelen, Levecque \& Louck, 2009). In 2010 bedroeg de responsratio 48,6\%. De steekproef omvatte 8.937 respondenten, waaronder $52 \%$ vrouwen. De leeftijd van de respondenten varieerde tussen 20 en 64 jaar $(M=41,50$ jaar; $S D=10,43$ jaar $) .5 \%$ van de respondenten behaalde een diploma lager onderwijs en $51 \%$ een diploma middelbaar onderwijs. $44 \%$ voleindigde hoger onderwijs, waarvan $15 \%$ een universitair diploma behaalde. Het merendeel werkte met een vast contract (95\%) en voltijds (71\%).

\subsection{Meetinstrumenten}

De vragenlijsten zijn in het Nederlands opgesteld en per post verzonden. De schalen in dit onderzoek zijn ontleend aan de Vragenlijst Beleving en Beoordeling van de Arbeid (VBBA) (Van Veldhoven \& Meijman, 1994). De verwerking van de data 
en de berekening van de schaalscores van de VBBA-schalen gebeurden conform de handleiding bij de VBBA-methode (Van Veldhoven et al., 2002). Zo werden de schaalscores gestandaardiseerd naar de range 0-100. Alle schalen kenden een goede betrouwbaarheid (Cronbach's alpha's in tabel 1).

Werkdruk is gemeten aan de hand van de VBBA-schaal 'werktempo en -hoeveelheid' (Van Veldhoven \& Meijman, 1994). De schaal bestaat uit elf items. Respondenten konden antwoorden op een 4-puntsschaal met als antwoordmogelijkheden 0 (nooit) tot 3 (altijd). Voorbeelditems zijn 'Heeft u te veel werk te doen?', 'Werkt u onder tijdsdruk?' en 'Heeft u te maken met een achterstand in uw werkzaamheden?'

Autonomie is gemeten aan de hand van de VBBA-schaal 'zelfstandigheid in het werk' (Van Veldhoven \& Meijman, 1994). Deze schaal bestaat uit elf items. Respondenten konden antwoorden op een 4-puntsschaal met als antwoordmogelijkheden 0 (nooit) tot 3 (altijd). Voorbeelditems zijn 'Kunt u zelf bepalen hoe u het werk uitvoert?', 'Kunt u meebeslissen over het tijdstip waarop iets af moet zijn?' en 'Heeft u invloed op de planning van uw werkzaamheden?'

Leermogelijkheden is gemeten aan de hand van de VBBA-schaal 'leermogelijkheden' (Van Veldhoven \& Meijman, 1994). Deze schaal bestaat uit vier items. Respondenten konden antwoorden op een 4-puntsschaal met als antwoordmogelijkheden 0 (nooit) tot 3 (altijd). De vier items zijn: 'Leert u nieuwe dingen op uw werk?', 'Biedt uw baan u mogelijkheden voor persoonlijke groei en ontwikkeling?', 'Biedt uw baan u mogelijkheden voor zelfstandig denken en doen?' en 'Geeft uw werk u het gevoel er iets mee te kunnen bereiken?'

Controlevariabelen In de analyses is steeds gecontroleerd voor drie sociaaldemografische kenmerken: geslacht, leeftijd en onderwijsniveau. Voor het meten van het onderwijsniveau is gevraagd naar het hoogste diploma: (1) geen of lager onderwijs, (2) lager middelbaar onderwijs, (3) hoger middelbaar onderwijs, (4) hoger onderwijs korte type (2 tot 3 jaar) en (5) hoger onderwijs lange type of universiteit (meer dan 3 jaar).

\subsection{Analyses}

De hypothesen zijn getoetst met OLS-regressieanalyse. In stap 1 van de analyse werden de controlevariabelen geslacht ( 0 = vrouw, $1=$ man), leeftijd en opleiding in het regressiemodel opgenomen, samen met de hoofdeffecten van werkdruk en autonomie en de interactieterm van werkdruk en autonomie. In stap 2 is de kwadraatterm van werkdruk toegevoegd. We volgden de procedure van Aiken en West (1991), en berekenden de interactieterm en de kwadraatterm op basis van de gecentreerde schaalscores van de onafhankelijke variabelen.

Om de hypothesen 1 tot en met 3 te toetsen zijn simple slope analyses (op $1 S D$ boven en $1 S D$ onder het gemiddelde) uitgevoerd. Doel was te bepalen (1) of het effect van werkdruk op leermogelijkheden afhangt van het niveau van werkdruk zelf (d.w.z. of het effect van werkdruk op leermogelijkheden positief is bij een lage mate van werkdruk en negatief bij een hoge mate van werkdruk), en (2) of het effect van werkdruk op leermogelijkheden afhangt van het niveau van autonomie (d.w.z. of het effect van werkdruk op leermogelijkheden altijd negatief is bij een lage mate van autonomie en altijd positief bij een hoge mate van autonomie). 
Tabel 1 Gemiddelden (M), standaarddeviaties (SD) en Pearson's productmomentcorrelaties voor de variabelen (Cronbach's alpha op diagonaal)

\begin{tabular}{llllll}
\hline & $\mathbf{M}$ & SD & $\mathbf{I}$ & $\mathbf{2}$ & $\mathbf{3}$ \\
\hline I. Werkdruk & 45.03 & 16.87 & $(.89)$ & $-.19 * *$ & .00 \\
2. Autonomie & 45.74 & 21.80 & & $(.91)$ & $.43^{* *}$ \\
3. Leermogelijkheden & 49.58 & 23.36 & & & $(.85)$ \\
\hline
\end{tabular}

$* p<.01 ; * * p<.001$

Tabel 2 Resultaten van de regressieanalyse met leermogelijkheden als afhankelijke variabele, gecontroleerd voor geslacht, leeftijd en opleidingsniveau $(N=8937)$

\begin{tabular}{lrr}
\hline & \multicolumn{1}{c}{ Model I } & \multicolumn{1}{c}{ Model 2} \\
\hline Geslacht & $.04 * * *$ & $.04 * * *$ \\
Leeftijd & $.10^{* * *}$ & $-.10^{* * *}$ \\
Opleiding & $.18^{* * *}$ & $.18 * * *$ \\
Werkdruk & $.06 * * *$ & $.06 * * *$ \\
Autonomie & $.41^{* * *}$ & $.41^{* * *}$ \\
Werkdruk x autonomie & $.09 * * *$ & $.08 * * *$ \\
Werkdruk kwadraat & & $-.03 * * *$ \\
$F$ & $407.79 * * *$ & $350.97 * * *$ \\
F change & $.24 * * *$ & $7.76 * * *$ \\
$R^{2}$ & $.25 * * *$ \\
$R^{2}$ change & & $.01 * * *$ \\
\hline
\end{tabular}

Noot. Kolommen vermelden gestandaardiseerde regressiecoëfficienten

$* p<.05 ; * * p<.01 ; * * *<<.001$

\section{Resultaten}

Beschrijvende statistieken De beschrijvende statistieken en correlaties tussen de onderzoeksvariabelen zijn weergegeven in tabel 1.

Hypothese toetsing De resultaten van de regressieanalyse zijn weergegeven in tabel 2. In stap 1 zijn de controlevariabelen (geslacht, leeftijd en opleiding) in het regressiemodel opgenomen, samen met de hoofdeffecten van werkdruk en autonomie en de interactieterm van werkdruk en autonomie. Dit model laat een directe test van Karasek's 'actief leren'-hypothese toe. De drie controlevariabelen bleken significant gerelateerd aan leermogelijkheden. Leermogelijkheden daalden met een hogere leeftijd en stegen met het opleidingsniveau. Mannen rapporteerden meer leermogelijkheden dan vrouwen. Verder toonden in stap 1 autonomie een sterke positieve samenhang met leermogelijkheden, en werkdruk een zwakke positieve samenhang. Ten slotte bleek de interactie tussen werkdruk en autonomie significant. 
Stap 2 onthulde dat werkdruk curvilineair gerelateerd is aan leermogelijkheden. Aanvullende simple slope analyses voor een hoge (1 SD onder het gemiddelde) en een lage (1 $S D$ boven het gemiddelde) mate van werkdruk lieten het volgende zien: op een hoog niveau van werkdruk hing een toename van de werkdruk samen met een afname in leermogelijkheden $(\beta=-.07, p<.001)$. Echter, op een laag niveau van werkdruk ging een toename van werkdruk gepaard met een toename in leermogelijkheden $(\beta=.10, p<.001)$. Deze resultaten ondersteunden de veronderstelling dat de samenhang tussen werkdruk en autonomie een omgekeerde U-vormige curve volgt. Dat is het geval bij gemiddelde autonomie (zie middelste curve in figuur 1 ).

Vervolgens zijn simple slope analyses gebruikt voor een gedetailleerder inzicht van de curvilineaire samenhang tussen werkdruk en leermogelijkheden bij een lage en hoge mate van autonomie. Bij een lage mate van autonomie (1 SD onder het gemiddelde) ging een toename van de werkdruk gepaard met een afname in leermogelijkheden wanneer de werkdruk laag was $(\beta=-.05, p<.001)$, maar die samenhang werd sterker bij een toename van de werkdruk $(\beta=-.10, p<.001)$. Deze bevinding is in lijn met onze verwachting dat bij lage autonomie een toename in werkdruk samengaat met een afname in werkplekleren, en deze negatieve relatie sterker wordt naarmate de werkdruk stijgt (zie onderste curve in figuur 1).

Bij een hoge mate van autonomie ( $1 S D$ boven het gemiddelde) ging een toename van de werkdruk gepaard met een toename in leermogelijkheden wanneer de werkdruk laag was $(\beta=.14, p<.001)$, maar die samenhang zwakte af bij een toename van de werkdruk $(\beta=.08, p<.001)$. Deze bevinding is in lijn met onze verwachting dat bij hoge autonomie een toename in werkdruk samengaat met een toename in werkplekleren, maar deze positieve relatie wordt zwakker naarmate de werkdruk stijgt (zie bovenste curve in figuur 1 ).

\section{Discussie}

In dit onderzoek bestudeerden we onder welke condities werkdruk positief, dan wel negatief gerelateerd is aan werkplekleren. We voorspelden, ten eerste, dat in het algemeen de relatie tussen werkdruk en werkplekleren een verloop kent van een omgekeerde U-vormige curve. We vonden hiervoor empirische steun in een grote, heterogeen samengestelde steekproef uit de Vlaamse beroepsbevolking: werkdruk hing samen met een toename van werkplekleren op lagere niveaus van werkdruk, maar met een afname van werkplekleren op hogere niveaus van werkdruk.

Vervolgens bekeken we de modererende invloed van taakautonomie op de relatie tussen werkdruk en werkplekleren. Zoals we verwachtten ging bij lage autonomie een toename in werkdruk gepaard met een afname in werkplekleren, en deze negatieve relatie werd sterker naarmate de werkdruk steeg. En bij hoge autonomie hing een toename in werkdruk samen met een toename in werkplekleren, maar deze positieve relatie zwakte af naarmate de werkdruk steeg. De omgekeerd 
U-vormige samenhang tussen werkdruk en werkplekleren trad bijgevolg alleen op bij een gemiddeld niveau van autonomie (zie figuur 1 ).

Onze resultaten tonen aan dat de relatie tussen werkdruk en werkplekleren niet onvoorwaardelijk rechttoe rechtaan is. Zoals we verwachtten is deze relatie afhankelijk van twee condities. Ten eerste, hangt die relatie af van het niveau van werkdruk zelf, in die zin dat werkdruk op (te) hoge niveaus van werkdruk zijn uitdagend potentieel verliest en werkplekleren belemmert. Ten tweede is die relatie afhankelijk van de mate van autonomie, aangezien een (te) laag niveau van autonomie de werknemer achterlaat met te weinig mogelijkheden voor flexibele aanpassing en actief engagement in probleemoplossing.

\subsection{Theoretische implicaties}

Eerdere studies naar de relatie tussen werkdruk en indicatoren van werkplekleren lieten conflicterende resultaten zien (voor een overzicht, zie Taris \& Kompier, 2005). Sommige studies vonden een positieve relatie (bijv. De Witte et al., 2007; Rau, 2006; Skule, 2004; Wielenga-Meijer et al., 2010), andere geen relatie (bijv. De Jonge et al., 1996; Houkes et al., 2001; Morrison et al., 2005; Van Ruysseveldt \& Taverniers, 2010; Van Ruysseveldt, Proost \& Verboon, 2011) en weer andere zelfs een negatieve relatie (bijv. Parker \& Sprigg, 1999; Taris et al., 2003; Van Ruysseveldt, Verboon \& Smulders, 2011). Een nadeel van dit eerdere onderzoek is dat het vooral gebruikmaakte van kleine en homogene datasets. Onderzoekers (bijv. Taris \& Kompier, 2005; De Witte et al., 2007) hebben dan ook geadviseerd om gebruik te maken van grootschalige en heterogene steekproeven teneinde een meer verfijnd en genuanceerd inzicht te verkrijgen in de relatie tussen werkdruk en werkplekleren. Een sterk punt van onze studie is daarom dat onze hypothesen zijn getoetst op een omvangrijke, heterogeen samengestelde en representatieve steekproef uit de Vlaamse beroepsbevolking. Dergelijke datasets zijn zeer geschikt voor het toetsen van curvilineaire verbanden omdat alle theoretisch mogelijke scores op een schaal goed vertegenwoordigd zijn. Onze studie stelt ons daarmee in staat de uiteenlopende resultaten van eerder onderzoek logisch en consistent met elkaar te verbinden door aan te tonen dat werkdruk en werkplekleren met elkaar samenhangen volgens een omgekeerd U-vormige curve (op gemiddelde niveaus van autonomie, zie De Jonge \& Kompier (1997), Karasek (1998), Taris \& Kompier (2005) en Wielenga-Meijer et al. (2010) voor eerder theoretische suggesties van een kromlijnig verband).

Bovendien ondersteunen onze resultaten de gedachte dat het niveau waarop de werkdruk overweldigend hoog wordt (in relatie tot werkplekleren) afhangt van de mate van autonomie in het werk (Wielenga-Meijer et al., 2010). Eerder onderzoek heeft geen eenduidig bewijs voor deze aanname uit het JDC-model (Karasek \& Theorell, 1990) geleverd. Weliswaar werd consistent bewijs gevonden dat een hoge mate van autonomie inderdaad een essentiële voorwaarde is opdat leren in het werk zou plaats kunnen vinden (voor een overzicht, zie: Wielenga-Meijer et al., 2010), maar het leek minder belangrijk of werkdruk hoog dan wel laag was (De Jonge \& Kompier, 1997; Holman \& Wall, 2002; Parker \& Sprigg, 1999; Taris \& Kompier, 2005; zie De Witte et al., 2007, voor een uitzondering). Onze resultaten tonen aan dat deze positieve invloed van een stijgende werkdruk bij een hoog 
niveau van autonomie stelselmatig afzwakt bij hogere niveaus van werkdruk. Bijgevolg voegt, bij een gegeven hoog niveau van autonomie, een toename van matige naar hoge werkdruk niet veel meer toe aan de mate van werkplekleren.

Wanneer we onze onderzoeksresultaten beschouwen in het licht van het JDCmodel (Karasek, 1979; Karasek \& Theorell, 1990), dan kunnen we stellen dat de meeste van de veronderstellingen uit dat model bevestigd worden. Zoals Karasek (1979) stelt is de combinatie van hoge (maar niet overweldigend hoge) werkdruk en hoge autonomie de beste promotor voor werkplekleren, omdat werknemers in deze actieve jobs tegelijk concrete mogelijkheden tot en een noodzaak of gevoel van urgentie ervaren om exploratief gedrag te etaleren, wat hen helpt om nieuwe, meer effectieve werkstrategieën te ontwikkelen en toe te passen.

Tegelijkertijd stelt ons onderzoek ons in staat om enkele van de veronderstellingen uit de 'actief leren'-hypothese te verfijnen en uit te breiden. Al eerder is gesteld dat hoge, maar niet overweldigend hoge, werkdruk bevorderlijk is voor het werkplekleren. Het huidige onderzoek breidt dit inzicht uit door de vaststelling dat op te hoge niveaus, werkdruk een hinderlijke factor wordt, aangezien een verdere toename van de werkdruk voorbij het punt van de overweldigend hoge werkdruk, een steeds negatievere invloed heeft op het niveau van werkplekleren. Dit inzicht wordt nog versterkt door de bevinding dat zelfs op hoge niveaus van autonomie een toename van matige naar hoge werkdruk nauwelijks toegevoegde waarde heeft in termen van het werkplekleren.

Ten slotte voorspelt de 'actief leren'-hypothese nog dat de laagste niveaus van werkplekleren zullen optreden in een situatie waarin zowel de werkdruk als de autonomie laag zijn (d.w.z., passieve jobs). Lage werkdruk perst het uitdagend potentieel uit het werk en, in combinatie met lage autonomie, dreigt het zelfs te leiden tot een voortschrijdend verlies van eerder verworven vaardigheden en bekwaamheden ('verleren'; Karasek, 1998; Taris \& Kompier, 2005). Onze resultaten spreken dit idee tegen. Bij een lage mate van autonomie hangt een toename van de werkdruk altijd samen met een daling van het werkplekleren en dit ongunstig effect wordt sterker op hoge niveaus van werkdruk. Werkplekleren word het meest gefrustreerd bij een lage mate van autonomie en een hoge mate van werkdruk (d.w.z., 'high strain' jobs), een type dat geassocieerd wordt met matige (maar geen lage) niveaus van werkplekleren (Karasek, 1979). Onze bevindingen spreken bijgevolg dit deel van de 'actief leren'-hypothese tegen, maar ze zijn wel in overeenstemming met eerder wetenschappelijk onderzoek dat aantoonde dat bij lage niveaus van autonomie, indicatoren van werkplekleren, zoals 'mastery', ongunstiger waren in jobs met hoge werkdruk, dan in jobs met lage werkdruk (Parker \& Sprigg, 1999; Taris et al., 2003).

Wat die werkdruk betreft suggereren onze onderzoeksresultaten vooral dat een te hoge werkdruk veel ongunstiger is voor werkplekleren dan een tekort aan werkdruk. Dit impliceert dat in het JDC-model meer aandacht zou moeten gaan naar de energie-uitputtende eigenschappen van (te) hoge werkdruk en de gevolgen daarvan op de effectiviteit van cognitieve processen (Eysinck \& Calvo, 1992; Holman \& Wall, 2002; LePine et al., 2004; Warr \& Downing, 2000), het terugplooien op geautomatiseerd werkgedrag (Frese \& Zapf, 1994; Taris et al., 2006), en werk- 
plekleren in het algemeen (Van Ruysseveldt \& Van Dijke, 2011; Van Ruysseveldt, Verboon \& Smulders, 2011).

\subsection{Beperkingen van het onderzoek}

Cruciaal voor onze onderzoeksvraag was de mogelijkheid om gebruik te maken van een bestaande, grote en heterogene steekproef. Het gebruik van een bestaande dataset heeft echter ook nadelen. Ten eerste hebben we onze toevlucht moeten nemen tot cross-sectionele data zodat we geen conclusies kunnen trekken aangaande de causaliteit in de veronderstelde verbanden tussen de variabelen in ons onderzoek. Eerdere studies op longitudinale data ondersteunen evenwel de veronderstelde causaliteit in de relaties tussen werkdruk en autonomie aan de ene kant en indicatoren van werkplekleren aan de andere kant, zoals de motivatie om te leren (Taris et al., 2003), 'feedback seeking behavior' (Taris \& Feij, 2004), effectieve probleemoplossing op het werk (Cunningham, Woodward, Shannon, MacIntosh, Lendrum, Rosenboom \& Brown, 2002), en gevoelens van 'mastery' (Holman \& Wall, 2002). Bovendien laten experimentele studies consistent een positief effect van werkdruk op leeruitkomsten aan (Wielenga-Meijer et al., 2010). Dit suggereert dat de voorgestelde causale relatie gegrond is in de realiteit.

Een tweede beperking die inherent is aan onze datakeuze is dat we moesten steunen op zelfrapportage door de respondenten. Dergelijke zelfrapportering kan aanleiding geven tot overschatting van de associatie tussen de onderzoeksvariabelen als gevolg van gedeelde methodevariantie. Het moet echter opgemerkt worden dat gedeelde methodevariantie geen rol speelt bij de studie van interactie-effecten, met inbegrip van kwadratische termen (die de interactie van een variabele met zichzelf betreffen). Interactie-effecten worden zelfs onderdrukt in regressieanalyses en velddata waardoor zulke effecten moeilijk aan te tonen zijn (Evans, 1985; McClelland \& Judd, 1993).

Een laatste beperking van ons onderzoek die we noemen vloeit voort uit de operationalisatie van de afhankelijke variabele. De afhankelijke variabele is gemeten als de mogelijkheden om te leren en niet de specifieke leeruitkomsten. Deze aanpak is in overeenstemming met eerder onderzoek in dit domein (bijv. Holman \& Wall, 2002, Morrison et al., 2005; Parker \& Sprigg, 1999; Rau, 2006). Van belang bij werkplekleren is de aanwezigheid van voldoende leermogelijkheden (Morrison et al., 2005; Rau, 2006; Wielenga-Meijer et al., 2006). Echter, zoals Rau (2006) benadrukt, impliceert de beschikbaarheid van leermogelijkheden nog niet dat de werknemer daadwerkelijk leert (zie ook: Wielenga-Meijer et al., 2006). Daar staat tegenover dat recent onderzoek van Van Ruysseveldt en Taverniers (2010) laat zien dat naarmate er meer leermogelijkheden in het werk beschikbaar zijn, werknemers ook een toename van de verwerving van nieuwe werkgerelateerde competenties rapporteren. Dit onderstreept de gedachte dat leermogelijkheden een realiteit in het werk zijn die op zich aandacht van onderzoekers verdient, maar dat deze leermogelijkheden ook beschouwd kunnen worden als een goede proxy voor werkplekleren, met inbegrip van leeruitkomsten. 


\subsection{Praktische implicaties}

Algemeen wordt erkend dat werkplekleren een vruchtbare bijdrage kan leveren aan de langere-termijncompetitiviteit van bedrijven, aan de werkgelegenheid en aan een brede inzetbaarheid van arbeidskrachten (Desjardins \& Tuijnman, 2005). Het vermogen om sneller en doelmatiger te leren dan de concurrenten is misschien zelfs het enige duurzame concurrentievoordeel dat overblijft in de hedendaagse kenniseconomie (Coetzer, 2007). Scherpe competitie kan ervoor zorgen dat managers en teamleiders onder druk staan om resultaten op de korte termijn te laten zien. Dit kan ervoor zorgen dat managers zich laten verleiden tot het opdrijven van de werkdruk om ambitieuze doelen te realiseren. Onze onderzoeksresultaten suggereren echter dat bedrijven hun succesvol presteren op de langere termijn in gevaar brengen door zich alleen op kortetermijndoelen en -ingrepen te richten.

De gunstige bijdrage van werkplekleren aan het realiseren van een duurzamer concurrentievoordeel brengt de vraag op de voorgrond hoe werkplekleren te bevorderen valt (cf. Marsick \& Volpe, 1999; Skule, 2004; Coetzer, 2007; Mayer \& Solga, 2008). Die vraag vormde de leiddraad in deze studie, waarbij - in lijn met een van de meest toonaangevende modellen op dit domein, het JDC-model (Karasek, 1979) - de klemtoon lag op de relatie tussen werkdruk en werkplekleren en de modererende rol van autonomie in die relatie. Organisaties kunnen profiteren van onze onderzoeksresultaten door jobs en taken zodanig te ontwerpen dat optimale combinaties van werkdruk en autonomie tot stand komen die moeten leiden tot de meest optimale niveaus van werkplekleren.

Een belangrijk inzicht uit ons onderzoek dat relevant is voor de praktijk van taak(her)ontwerp is dat een toename van de werkdruk alleen onder specifieke condities samenhangt met een toename van het werkplekleren. Concreet stimuleert een stijging van de werkdruk het werkplekleren vooral op lage en matige, maar niet op (te) hoge niveaus van werkdruk, althans wanneer tegelijk de autonomie matig of hoog is. Wanneer de werkdruk zich reeds op hoge niveaus situeert, dan kan het werkplekleren op zijn best nog marginaal bevorderd worden als ook de autonomie zich op een hoog niveau bevindt. Maar bij lage of matige niveaus van autonomie is een (te) hoge werkdruk schadelijk voor het werkplekleren. Wanneer men in een organisatie een beleid ter bevordering van het werkplekleren wil voeren, dan lijkt het raadzaam om te focussen op jobs die zich kenmerken door een lage of matige autonomie, en maatregelen te treffen ter verhoging van die autonomie. Dat is effectiever dan in te grijpen in de autonomie van jobs die zich al door hoge niveaus van autonomie kenmerken.

In ieder geval heeft werkplekleren baat bij maatregelen die bedoeld zijn om het niveau van werkdruk onder controle te houden. Van een (te) hoge werkdruk is sprake wanneer de werknemer in de werksituatie het gevoel krijgt dat de energiereserves uitgeput geraken en daarmee samenhangende spannings- en stressverschijnselen ervaart, want daarmee gaan problemen als cognitief onderpresteren gepaard. Maar ook wanneer de werknemer het gevoel heeft dat er alleen nog ruimte is voor direct-productieve activiteiten en geen tijd overblijft voor reflectie, exploratie en experimentatie - activiteiten die een noodzakelijke voedingsbodem 
vormen voor werkplekleren - kan gewag gemaakt worden van een (te) hoge werkdruk.

Duurzaam personeelsmanagement ziet zich voor de uitdaging gesteld om, onder meer via de praktijk van taak(her)ontwerp, het realiseren van productiviteitsstijgingen te verzoenen met de noodzaak om bedrijfssucces op de lange termijn succes veilig te stellen door het stimuleren van werkplekleren. Daarvoor is een combinatie van werkdruk en autonomie gewenst die de werknemer toelaat om min of meer vrij te experimenteren met alternatieve werkstrategieën om de werkdoelen te behalen, mogelijkheden tot flexibele aanpassing te bieden en de meest doelmatige instrumenten ter beschikking te stellen waarmee de werkinhoud en -omstandigheden daadwerkelijk bijgesteld kunnen worden in het licht van de gekozen werkstrategieën.

\section{Praktijkbox}

Wat betekenen de resultaten voor de praktijk?

- Een stijging van de werkdruk stimuleert het werkplekleren vooral op lage en matige niveaus van werkdruk, althans wanneer tegelijk de autonomie matig of hoog is. Op hoge niveaus van werkdruk kan het werkplekleren nog slechts marginaal bevorderd worden en dan alleen als ook de autonomie zich op een hoog niveau bevindt.

- Het werkplekleren is bijgevolg gebaat bij maatregelen die bedoeld zijn om het niveau van werkdruk onder controle te houden.

- Bij lage of matige niveaus van autonomie is een (te) hoge werkdruk steeds schadelijk voor het werkplekleren.

- Het is daarom raadzaam bij interventies te focussen op jobs met een lage of matige autonomie, en maatregelen te treffen ter verhoging van die autonomie.

- Via taak(her)ontwerp kunnen organisaties streven naar voor werkplekleren optimale combinaties van werkdruk en autonomie. In het algemeen zijn die combinaties van werkdruk en autonomie wenselijk die de energiereserves van de werknemer intact laten, die tijd en ruimte laten voor leeractiviteiten zoals reflectie, exploratie en experimentatie en die voldoende mogelijkheden laten voor actief ingrijpen in de werksituatie.

\section{Literatuur}

Aiken, L.S. \& West, S.G. (1991). Multiple regression: Testing and interpreting interactions. Newbury Park, CA: Sage.

Bakker, A. \& Demerouti, E. (2007). The Job Demands-Resources Model: state of the art. Journal of Managerial Psychology, 22, 309-328.

Bourdeaud'hui, R. \& Vanderhaeghe, S. (2007). Methodologische nota Vlaamse Werkbaarheidsmonitor. Brussel: SERV. 
Coetzer, A. (2007). Employee perceptions of their workplaces as learning environments. Journal of Workplace Learning, 19, 417-434.

Cunningham, C., Woodward, C., Shannon, H., MacIntosh, J., Lendrum, B., Rosenboom, D. \& Brown, J. (2002). Readiness for organizational change: A longitudinal study of workplace, psychological and behavioural correlates. Journal of Occupational and Organizational Psychology, 75, 377-392.

De Jonge, J., Janssen, P. \& Van Breukelen, G. (1996). Testing the demand-control-support model among health-care professionals: A structural equation model. Work \& Stress, 10, 209-224.

De Jonge, J. \& Kompier, M. (1997). A critical examination of the demand-control-support model from a work psychological perspective. International Journal of Stress Management, 4, 235-258.

Desjardins, R. \& Tuijnman, A. (2005). A general approach for using data in the comparative analyses of learning outcomes. Interchange, 36, 349-370.

De Witte, H, Verhofstadt, E. \& Omey, E. (2007). Testing Karasek's learning and strain hypotheses on Young workers in their First job. Work \& Stress, 21, 131-141.

Ellström, P-E. (2001). Integrating learning and work: problems and prospects. Human Resource Development Quarterly, 12, 421-435.

Evans, M. (1985). A Monte Carlo study of the effects of correlated method variance in moderated multiple regression analysis. Organizational Behavior and Human Decision Processes, 36, 305-323.

Evers, A., Van Vliet-Mulder, J. \& Groot, C. (2000). Documentatie van test en testresearch in Nederland. Testbeschrijvingen. Assen: Van Gorcum \& Comp. BV.

Eysinck, M. \& Calvo, M. (1992). Anxiety and performance: The processing efficiency theory. Cognition and Emotion, 6, 409-434.

Frese, M. \& Zapf, D. (1994). Action as the core of work psychology: A German approach. In H. Triandi, M. Dunnette \& L. Hough (Eds.), Handbook of industrial and organizational psychology (Vol. 4, pp. 271-340). Palo Alto: Consulting Psychologists Press.

Hobfoll, S. (2002). Social and psychological resources and adaptation. Review of General Psychology, 6, 307-324.

Holman, D. \& Wall, T. (2002). Work characteristics, learning-related outcomes, and strain: a test of competing direct effects, mediated, and moderated models. Journal of Occupational Health Psychology, 7, 283-301.

Houkes, I., Janssen, P., De Jonge, J. \& Nijhuis. (2001). Specific relationships between work characteristics and intrinsic work motivation, burnout and turnover intention: A multi-sample analysis. European Journal of Work and Organizational Psychology, 10, $1-23$.

Karasek, R. (1979). Job demands, job decision latitude, and mental strain: implications for job redesign. Administrative Science Quarterly, 24, 285-307.

Karasek, R. (1998). Demand-control model: a social, emotional, and physiological approach to stress risk and active behaviour development. In J. Stellmann (Ed.), Encyclopedia of occupational health and safety. $4^{\text {th }}$ ed. (pp. 34.6-34.14). Geneva: International Labour Office.

Karasek, R. \& Theorell, T. (1990). Healthy work: stress, productivity and the reconstruction of working life. New York: Basic Books.

Lee, R. \& Ashforth, B. (1996). A meta-analytic examination of the correlates of the three dimensions of job burnout. Journal of Applied Psychology, 81, 123-133.

LePine, J., LePine, M. \& Jackson, C. (2004). Challenge and hindrance stress: relationships with exhaustion, motivation to learn, and learning performance. Journal of Applied Psychology, 89, 883-891. 
Marsick, V. \& Volpe, M. (1999). The nature and need for informal learning. Advances in Developing Human Resources, 1, 1-9.

Mayer, K.U. \& Solga, H. (2008). Skill formation: Interdisciplinary and cross-national perspectives. Cambridge: Cambridge University Press.

McClelland, G. \& Judd, C. (1993). Statistical difficulties of detecting interactions and moderator effects. Psychological Bulletin, 114, 376-390.

Morrison, D., Cordery, J., Girardi, A. \& Payne, R. (2005). Job design, opportunities for skill utilization, and intrinsic job satisfaction. European Journal of Work and Organizational Psychology, 14, 59-79.

Parker, S, Chmiel, N. \& Wall, T. (1997). Work Characteristics and employee well-being within a context of strategic downsizing. Journal of Occupational Health Psychology, 2, 289-303.

Parker, S. \& Sprigg, C. (1999). Minimizing strain and maximizing learning: The role of job demands, job control, and proactive personality. Journal of Applied Psychology, 84, 925-939.

Parker, S., Wall, T. \& Cordery, J. (2001). Future work design research and practice: Towards an elaborated model of work design. Journal of Occupational and Organizational Psychology, 74, 413-440.

Paulsson, K., Ivergård, T. \& Hunt, B. (2005). Learning at work: competence development or competence-stress. Applied Ergonomics, 36, 135-144.

Rau, R. (2006). Learning opportunities at work as predictor for recovery and health. European Journal of Work and Organizational Psychology, 15, 158-180.

Schaufeli, W., Bakker, A. \& Van Rhenen, W. (2009). How changes in job demands and resources predict burnout, work engagement, and sickness absenteeism. Journal of Organizational Behavior, 30, 893-917.

Skule, S. (2004). Learning conditions at work: A framework to understand and assess informal learning in the workplace. International Journal of Training and Development, $8,8-20$.

Taris, T. (2006). Bricks without clay: On urban myths in occupational health psychology. Work \& Stress, 20, 99-104.

Taris, T., Kompier, M., De Lange, A., Schaufeli, W. \& Schreurs, P. (2003). Learning new behaviour patterns: a longitudinal test of Karasek's active learning hypothesis among Dutch teachers. Work \& Stress, 17, 1-20.

Taris, T. \& Kompier, M. (2005). Job characteristics and learning behavior: Review and psychological mechanisms. In P. Perrewé \& D. Ganster (Eds.), Research in occupational stress and well-being: Exploring interpersonal dynamics: Vol. 4 (pp. 127-166). Amsterdam: JAI Press.

Taris, T. \& Feij, J. (2004). Learning and strain among newcomers: a three-wave study on the effects of job demands and job control. The Journal of Psychology, 138, 543-563.

Taris, T., Kompier, M. \& Wielenga-Meijer, E. (2006). Leren op het werk: Een handelingstheoretisch perspectief. Gedrag \& Organisatie, 19, 69-90.

Van der Doef, M. \& Maes, S. (1999). The Job Demand-Control(-Support) Model and psychological well-being: a review of 20 years of empirical research. Work \& Stress, 13, 87-114.

Vanroelen, C., Levecque, K. \& Louckx, F. (2009). Psychosocial working conditions and selfreported health in a representative sample of wage-earners: a test of the different hypothesis of the Demand-Control-Support-Model. International Archive of Occupational and Environmental Health, 82, 329-342.

Van Ruysseveldt, J. \& Taverniers, J. (2010). Al werkend leren. De actief leren-hypothese van Karasek revisited. Gedrag \& Organisatie, 23, 1-18. 
Van Ruysseveldt, J. \& Van Dijke, M. (2011). When are workload and workplace learning opportunities related in a curvilinear manner? The moderating role of autonomy. Journal of Vocational Behavior, 79, 470-483.

Van Ruysseveldt, J., Verboon, P. \& Smulders, P. (2011). Job resources and emotional exhaustion: the mediating role of learning opportunities. Work \& Stress, 25, 205-223.

Van Ruysseveldt, J., Proost, K. \& Verboon, P. (2011). The Role of Work-home Interference and Workplace Learning in the Energy-depletion Process. Management Revue, 22, 151-168.

Van Veldhoven, M. \& Meijman, T.F. (1994). Het meten van psychosociale arbeidsbelasting met een vragenlijst: de vragenlijst beleving en beoordeling van de arbeid (VBBA). Amsterdam: NIA.

Van Veldhoven, M., Meijman, T., Broersen, J. \& Fortuin, R. (2002). Handleiding VBBA. Amsterdam: SKB.

Warr, P. \& Downing, J. (2000). Learning strategies, learning anxiety and knowledge acquisition. British Journal of Psychology, 91, 311-333.

Wielenga-Meijer, E., Taris, T., Kompier, M. \& Wigboldus, D. (2006). Understanding taskrelated learning: when, why, how and who? In S. McIntyre \& J. Houdmont (Eds.), Occupational health psychology: European perspectives on research, education and practice (Vol. 1, pp. 59-81). Maia: ISMAI publishers.

Wielenga-Meijer, E., Taris, T., Kompier, M. \& Wigboldus, D. (2010). From task characteristics to learning: A systematic review. Scandinavian Journal of Psychology, 51, 363-375.

\section{When does workload promote workplace learning opportunities, and when does workload hinder workplace learning opportunities?}

Joris Van Ruysseveldt \& Marius van Dijke, Gedrag \& Organisatie, volume 25, March 2011, nr. 1, pp. 28-44.

Building on theoretical frameworks like the Job Demands Control model we tested whether the relationship between workload and employees' experiences of opportunities for workplace learning is of an inverted u-shaped nature. Furthermore we researched whether autonomy moderates this relationship. We predicted that at moderate levels of autonomy rising workload was associated with increasing learning opportunities at low levels of workload, but with decreasing learning opportunities at high levels of workload. Also, we predicted that low autonomy prevents positive effects of moderate workload from materializing whereas high autonomy makes high workload less destructive to the learning process. We found support for these ideas in a large and heterogeneous sample of Flemish working adults (FWM, 2010). These results integrate conflicting prior findings and extend Karasek's (1979) active learning hypothesis. They also have clear implications for job redesign practices aiming to promote workplace learning opportunities.

Key-words: Job Demands Control model, action theory, informal learning, job redesign 